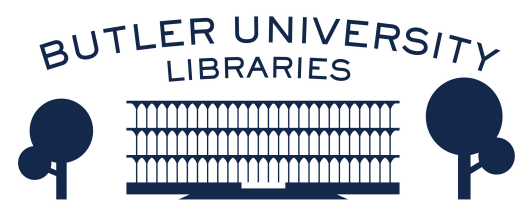

Journal of Hindu-Christian Studies

\title{
Narasimha, Lord of Transitions, Transformations, and Theater Festivals: God and Evil in Hindu Cosmology, Myth, and Practice
}

\author{
Lavanya Vemsani \\ Shawnee State University
}

Follow this and additional works at: https://digitalcommons.butler.edu/jhcs

Part of the Hindu Studies Commons, and the Religious Thought, Theology and Philosophy of Religion Commons

\section{Recommended Citation}

Vemsani, Lavanya (2016) "Narasimha, Lord of Transitions, Transformations, and Theater Festivals: God and Evil in Hindu Cosmology, Myth, and Practice," Journal of Hindu-Christian Studies: Vol. 29, Article 5. Available at: https://doi.org/10.7825/2164-6279.1628

The Journal of Hindu-Christian Studies is a publication of the Society for Hindu-Christian Studies. The digital version is made available by Digital Commons @ Butler University. For questions about the Journal or the Society, please contact cbauman@butler.edu. For more information about Digital Commons @ Butler University, please contact digitalscholarship@butler.edu. 
Vemsani: Narasimha, Lord of Transitions, Transformations, and Theater Fest

\title{
Narasimha, Lord of Transitions, Transformations, and Theater Festivals: God and Evil in Hindu Cosmology, Myth, and Practice
}

\author{
Lavanya Vemsani \\ Shawnee State University
}

Introduction

This paper focuses on the multi-faceted nature of the divine depicted in Narasimha and the unique perspectives on God and evil offered by the myths of Narasimha, which is also subliminally represented within the religious practice and performance traditions associated with Narasimha.

Narasimha is the multifaceted boundarydefying Hindu deity frequently subjected to confusion and misrepresentation. Although the lion form of Narasimha is simple, the nature of divinity represented through the narrative descriptions containing the cosmic symbols and activities of Narasimha is complicated. The central purpose for the incarnation of Narasimha is to overturn the already inverted world order of Kritayuga to return it to a state of harmony, thus attaining a balance between good and evil for the next era, the Tretayuga.
Chronologically the life of Hiranyakaśipu and the incarnation of Narasimha take place in the last part of the Kritayuga (Satyayuga), the first of the four ages (yugas) in a Kalpa (Aeon). Kritayuga is described as the golden age, according to the yugadharma, in which the three worlds (Devalokka, Bhūlōka, and Pātālalōka) have existed in perfect balance. Gods stayed at the top in Devaloka, receiving homage from the humans living in the middle on the Bhūlōka (Earth), while the demons are kept at bay in the netherworld, the Pātālalōka. Hence, the Narasimha story is helpful to understand not only the theological perspectives on the nature of the divine, but also the transitions and transformations in the cosmological balance of good and evil as represented through the unique portrayal of Narasimha. It should be added that religious practice centered on Narasimha is an especially significant aspect of religious life in the eastern

Lavanya Vemsani is an award winning scholar and Professor of History at Shawnee State University in Ohio, specializing Indian History and Religions. She holds a doctorate in Religious Studies from McMaster University and a doctorate in History from the University of Hyderabad. She has published articles on subjects of ancient Indian history and religions as well as on the current history of India. She is the author of Hindu and Jain Mythology of Balarama (2006) and Krishna in History, Thought, and Culture: An Encyclopedia of the Hindu Lord of Many Names (2016). She is currently working on two book projects: India: A New History and Ancient Settlement Patters of South India. She is the editor of International Journal of Dharma and Hindu Studies and Associate Editor of Journal of South Asian Religious History. 
Indian coastal states on the Indian Ocean, Andhra Pradesh (presently divided into Andhra Pradesh, Telangana ${ }^{2}$ ), Orissa, and Tamil Nadu, which results in unique Narasimha festivals celebrated annually in numerous temple towns across these states accompanied by theater performances.

Therefore, this paper has three important objectives: First, to examine Narasimha legends in the classical texts and local legends to understand the representation of evil. Second, to analyze the Narasimha myths to understand the nature of divine as represented by Narasimha. Third, to examine the religious theatrical performance and other religious vows associated with Narasimha to understand the reflection of the notions of divinity and evil as exemplified in popular religious practice.

Based on the available literary and sculptural representations it can be understood that the Narasimha myth was standardized between 300 B.C.E - 300 C.E. with little variation in the basic elements of the narrative ${ }^{3}$. Narasimha ${ }^{4}$ or motifs associated with lion are commonly encountered in association with almost all of India's major religions, including Hinduism and Jainism, as well as the Hindu folk traditions (Eschmann 1978; Guy 2015; Vemsani 2009 and 2016). The Narasimha story is stunningly uniform across the more than eighteen available versions of the Mahāpurānas, which narrate it in their own way, and hence it could be categorized into a mere three groups based on the presence or absence of certain basic elements of the story (Soifer 1991: 74). Uniformity across numerous versions and the lack of similar myths from any other religious tradition incorporating a fully developed lion form datable to such early period (300-200 B.C.E) makes it possible for the origin of Narasimha only in the context of Vaishnava incarnations ${ }^{5}$. Therefore, it is possible to presume that Narasimha is an innovative incarnation of Vishnu incorporating cosmological and cosmogonic adaptations dictated by the nature of evil perpetrated through the actions of Hiranyakaśipu. Hence, the Narasimha incarnation incorporates a fully developed lion form along with unique cosmological principles representing transitory elements such as a sanguinary nature and end of time symbolism that are not commonly associated with Vishnu.

Initially the Narasimha myths attracted the attention of scholars in the field of Hindu text critical studies with the goal of isolating the text kernel to find the original concepts associated with Narasimha (Swain 1975: 1; Biardeau 1975: 1) in classical Hinduism. Narasimha is also considered an independent deity, conceived of as an embodiment of a numinous 'potency' (Otto 1942:17). It is also noted that the origin stories of Narasimha incorporate the cosmological and theological nature of Vaishnavism (Soifer 1991; Rosen 2005; Gail 1983; Meister 1996).

I will begin my examination of the nature of evil in Hinduism with an examination of the legend of Narasimha, which portrays reversals, transformations, and transitions as a consequence of the preponderance of evil.

\section{Nature of Evil in the Legend of Narasimha}

The concept of evil in Hinduism is very complex, as it varies based on time, place and also individual. World order or harmony is typical of time and place. The Narasimha incarnation takes place in Kritayuga, a time also known as the golden age, during which all the universe was in complete harmony and dharma was fully prevalent. The term, dharma (Vedic rta) represents the concerns of evil, good and moral 
order of the earthly realm as well as its connection to the Devalōka (World of Gods) and Pātālalōka (World of Demons) (Holdrege 2004: 213-248), in other words the cosmological relation of the three worlds (Trilokya). Kritayuga ${ }^{6}$ is the first age in a Kalpa (aeon) in which dharma is fully prevalent (Kloetzli and Hiltebeitel 2004:568-569) and adharma is not known within the created universe. This cosmological balance is disturbed by the asura Hiranyakaśipu when he assumed world leadership through his boon from the God Brahma (Brahmandapurāna 2.5.1522). Therefore a reversal of world order in Kritayuga meant that evil took over the greatest good ever to have been present on the Earth.

Life on Earth is subject to time, which should follow a circular or repetitive path, as noted in the example of samsāra (circle of life interspersed by birth and death). Accordingly, any results of actions on Earth acquire karma, hence, karma and rebirth are the central aspect of life on the Earth (Creel 1986: 1-15; Tull, 1889; Eliade 1959). The world of Gods (Devalokka) and the world of Demons (Pātāla lōka) are connected to the Earth as well as their actions, deriving the name of three worlds, triloka. Therefore, the Hindu universe could be understood as "mutually resembling interconnected, but also hierarchically distinguished, ranked, components" (Smith, 1994: vii). Therefore, karma $^{7}$, actions, of/in one world are connected to the other worlds. Although, in general demons represent evil and Gods represent good, the line blurs frequently, as in the mythology of Narasimha, which is characterized by Narasimha transposing most of the boundaries denoting good and evil. Human life and good and evil (karma within the bounds of dharma) are therefore not confined merely to the Earth, but are connected to the cosmic order of the three worlds ${ }^{8}$. Thus Vishnu is incarnated whenever dharma is in imbalance.

As karma varies based on time, place, and individual, so also the nature of evil (the result of bad actions) varies according to place and time. The Narasimha myth demonstrates that evil is not something that could be found in a personified form within creation, but only noticed through the evil actions of someone who has strayed from the rightful path (dharma). For example, Hiranyakaśipu, even though depicted as an evil being in the Narasimha myth and noted as an arch enemy of Vishnu in this life, was a guardian as well as a staunch devotee of Vishnu in his original life (Bhāgavatapurāna. Skandha III. Ch. 15; Śrīnarasiṃhapurānam). Therefore, evil or good is rather an attribute (a type of behavior) that could be present in anything or anyone. Hence, motivated by his selfish desires Hiranyakaśipu did not only invert the world order displacing Gods and harassing humans (see Section 1.1 below), but as a next step to conceal his greed, he also began mistreating his own child ${ }^{9}$ (see Section 1.2 below), as he tried to have his son, Prahlāda, killed so that he could suppress the only one veritable voice of opposition to his evil deeds.

The effects of a reversed world order (lōka dharma) are noticed both at the cosmological level, and also at the individual level. Reversal of the world order is more obvious in the characteristics of the central deity and main devotee of the story. The demon-born child Prahlada acquired sātvika qualities of a devotee of Vishnu, while a God Narasimha acquired the sanguinary and fiery nature commonly associated with demons.

\subsection{Cosmic Evil in the Actions of Hiranyakaśipu}


Hiranyakaśipu performed severe austerities (tapas) $)^{10}$ for about twelve-thousand years (11000 in Harivamsa and Brahmapurāna; 11500 in Vishnudharmottarapurāna), finally obtaining the grace of the God Brahma, who gave him a special boon permitting him near invincibility. He may not be killed by Gods, demons, gandharvas, yakshas, nāgas, rākshasas, men, or piśācas; he cannot be cursed by Rishis (sages), killed by weapons, swords, rocks or trees, and if the unfortunate event of his death were to occur, it should neither be wet nor dry, neither day nor night, and if anyone were at all able to kill Hiranyakaśipu, it should be achieved by one stroke of the hand without spilling any blood on the Earth (Harivamsa 41; Brahmāpurāna 213.4479; Vishnudharmottarapurāṇa 1.54).

However, it is the second part of Hiranyakaśipu's boon that overturns the harmony of the world by reversing the world order. The second part of his boon includes his desire to encompass the universe, to be the sun, moon, wind, and fire, water, air, ether, and the universe itself, as well as to become the guardians of the four regions of the world (lōkapalas) replacing Indra, Varuna, Kubera, and Yama (Matsyapurāna 161-163). This second desire interferes with the role of Vishnu (derived from the Sanskrit root vis - to spread) who pervades the world, thereby maintaining a balance between good and evil (Gupta 1974). Hiranyakaśipu's actions therefore resulted in a cosmic reversal, and hence his actions resulted in a cosmic evil requiring a cosmic reaction.

The purānas include extensive descriptions of the actions of Hiranyakaśipu, following his special boon. Hiranyakaśipu began his reign of terror harassing people, overpowering the sages, razing their hermitages, conquering the Gods, and usurping their sovereignty over the trilōkas (three worlds). The inversion is complete when Hiranyakaśipu placed the asuras (demons) at the top receiving the sacrifice, while relegating Gods to the nether world undeserving of sacrifice. Thus a complete reversal of the world order is accomplished by Hiranyakaśipu (Śivapurāna II.5; Kūrmapurāṇa I. 15.18-72). Hiranyakaśipu therefore perpetrated evil at the cosmic level that required a cosmic intervention. It was then possible only for Vishnu as someone with the power to rebalance the world to enter the world assuming the characteristics of the inverted world, which could then be overturned by him, thereby righting the course of the inverted universe. Hence, Narasimha's actions reflect the counteractions to bring the world order back to its original state of proper harmony. Therefore, it was neither merely 'superfluous' (Hacker 1959: 594) nor Śaivite (Soifer 1991: 102) nor 'Rudraic' (Biardeau 1976: 183) influence, as will be shown below, that Narasimha enters the world originating from apparently nothing (the hollowed center) of the pillar displaying both a fierce and sanguine nature atypical of the incarnations of Vishnu in general.

Hiranyakaśipu also perpetrated evil at the individual level. Although he exhibited the six sins of desire, anger, greed, infatuation, lust, and jealousy (kāma, krōdha, lōbha, mōha, mada, mātsarya ${ }^{11}$ ) in his efforts to establish his sovereignty over trilōkya, he notably demonstrated an excessive amount of the three (Bhagavadgita.16.22) worst sins of all: desire, anger, and greed (kāma, krōdha, lōbha). While exhibiting these sinful behaviors Hiranyakaśipu perpetrated the most horrendous actions towards his son, Prahlāda. Although the Prahlāda story was considered an add-on to the story of Narasimha (Hacker, 1959), that might 
not be the case, as it perfectly fits with the central theme of the Narasimha myth: reversals, transitions, and transformation.

\subsection{Hiranyakasipu's Actions Towards the Child Prahlāda}

As a born devotee of Vishnu, Prahlāda began praising Vishnu as a child, while criticizing his father Hiranyakaśipu for his evil actions. Taken over by greed and excessive desire for power Hiranyakaśipu could not heed the words of his son to return the world back to its original course and cede the world leadership to Vishnu, but was instead overcome with anger. Hiranyakaśipu then ordered his trusted councilors and security guards to put his own son, Prahlāda, to death (Vishnupurāna I.18) while Vishnu appeared in the form of Narasimha to save him (Vishnupurāna. I. 19).

Therefore the Narasimha myth depicts evil with cosmic dimensions represented by the suspended reality, as the three worlds are inverted and lose their original course of progress and harmony that was typical of the yugadharma of Kritayuga. Secondly, that Hiranyakaśipu exhibited the characteristics of the most evil individual through his actions demonstrating utter disregard for life under the influence of desire, anger, and greed. He was so inebriated by his lust for power that he was overcome by immense anger so as to order his own child Prahlāda to be put to death. As Hiranyakaśipu represented the greatest evil, so also the God incarnate Narasimha represented the greatest divinity. I will consider below the nature of the divine as represented in the legends of Narasimha.

\section{Nature of the Divine: Narasimha as Avatāra and Vyūha of Vishnu}

The concept of God is complex in the Narasimha myth. An examination of the Narasimha legends in the purānas reveals that the early concept of lion $^{12}$ appears consistently in connection with divinity in the incarnation of Narasimha and in Hinduism. Incidentally, another occurrence of lion-face is noticed in connection with this myth in association with the demons (asuras) Simhika, sister of Hiranyakaśipu, and her son, $R a \bar{h} u^{13}$, a nephew of Hiraṇyakaśipu (Brahmāndapurāna II.6.20; Vāyupurāna. 68.19-20;), who have been described to possess a lion-face. Therefore, it can be understood here that Narasimha concurrently demonstrates or incorporates the contradictory aspects of the demoniac appearance within divine nature (see footnote 12 and 13 below), although preserving his inner divine nature. The assumption of lion form in the case of Narasimha here is not merely symbolic, but indicative of reversal, a characteristic of transitional/liminal world ${ }^{14}$. In order to counteract the complete evil (as noted in the reversal of the world order in Kritayuga) Narasimha acquired the qualities suitable to enter the inverted world, that of the familial form of the demon. Therefore, it could be understood that the partial lion form of Narasimha (Man-lion) is indicative of the reversal, where the divinity assumed an unusual form in order to counteract the forces of the inverted world order. Prevalent correlation of the lion form with demonic beings, as noted in the family of Simhika, sister of Hiranyakaśipu, is also supportive of this transitional, temporal nature of Narasimha. The transitional nature of the lion form of Narasimha is also noted from the classical Hindu texts depicting Narasimha as an ephemeral form, which is quickly withdrawn soon after vanquishing Hiranyakaśipu. 
Narasimha, in overturning the three-worlds so as to return it to right order, functions as a descent of Vishnu within and beyond the created universe, simultaneously as an avatāra and also a vyūha. Another incident in which a descent of Vishnu is simultaneously identified as an avatāra and a vyūha $a^{15}$ is noted in the legends of Krishna and his brother Balarāma. Krishna and Balarāma are identified as avatāras as they ended the evil in the world, and then ended the era (Dvāparayuga). They are also identified as vyūhas Samkarshna and Vāsudeva subsequently while signaling the beginning of the next era, the Kaliyuga. Similarly, Narasimha entered the creation in Kritayuga to end evil and also end the era of Kritayuga, thus beginning the next era, Tretayuga, as vyūha Samkarshana. Therefore, texts further emphasize the importance of Narasimha beyond creation by presenting Narasimha as vyūha Samkarashana. Therefore Narasimha acted as the destroyer of evil (avatāra) for Kritayuga and as the initiator (vyūha) of the next era, Tretayuga by righting the course of the world. Therefore, the portrayal of Narasimha here exemplified the divinity in both cosmic and worldly contexts.

The texts further incorporate the synthesis of avatāra-vyūha forms of Vishnu ${ }^{16}$ to further emphasize the special position of Narasimha in Hinduism as a symbol of transitions/liminality and transformation, but not bounded by limited identity. Narasimha entered the inverted creation as avatāra Narasimha, but as vyūha Samkarshana facilitated the return of the world to its rightful path (dharma). Therefore I suggest that in the Vaishnava tradition, Narasimha's position is cosmologically mandated, leonine in nature, but fully divine, which simultaneously represents both an incarnation (avatāra) within the created world and a vyūha separate from the created world (Grünendahl 1997). Narasimha is also liminal in nature since he assumed the physical qualities suitable for an inverted world only to correct its course of the world soon, and also to return to his own true nature.

My examination of the Narasimha stories therefore reveals that the full-fledged lionformed divinity appears only in connection with Narasimha, and it is symbolic of the transitions and transformation undertaken by the divine to restore world order and also vanquish evil prevalent in the world. True to the established conventions of transition, the classical Vaishnava theology depicts Narasimha as an ephemeral form with a quick withdrawal of this form. ${ }^{17}$

Narasimha is an incarnation (avatāra) of Vishnu, but his constant representation as vyūha establishes that Narasimha is not merely a part of the created world, but as the vyūha form of Vishnu, he performs the cosmic role to facilitate a proper functioning of creation by returning the world back to its original order. This may again represent Narasimha in his transitional and transformative role, since, Narasimha returns creation to its original order of harmony as an avatära, while leading it to the next era as vyūha.

Such transitional and transformative forms of Narasimha symbolic of the dual nature of the divinity also predominate in the devotional and ritual traditions associated with Narasimha. Therefore, I will consider in section 3 below the popular religious practices and devotional traditions associated with Narasimha to highlight the unique aspects of Narasimha as they are adapted for popular practice.

\section{Narasimha in Religious Practice and Performance Traditions}


The popular practice of religion is frequently dominated by mundane concerns rather than theological questions. However, theology is uniquely expressed in subtle ways through popular practice. Narasimha's transitional and transformative attributes are also at the root of numerous popular devotional traditions noticed in Andhra Pradesh, Tamil Nadu and Orissa. My discussion of the Narasimha narratives in the above sections of this paper showed that the lion form is representative of transitional and transformative attributes of Narasimha. These two aspects are at the core of devotional and ritual practices associated with Narasimha. Two of the most popular practices associated with Narasimha are the Bhägavatamela and vows to cure disease (diksha), and remove other difficulties, which inherently contain the elements of transition and transformation. Therefore reversals and transitions noted in the Narasimha story are also commonly found in the rituals and practice.

Doors, especially the main door of the house, are considered liminal, separating the passage between the inner and the outer worlds. Regular Hindu practice of life cycle rituals incorporates the doorframe and doorstep of the main entrance sometimes to receive special rituals (rites of passage) that signify liminal stages of life such as birth, death, and marriage (Turner 1977: 94-130; Gennep 1909). Liminality is often compared to "being in the womb, to invisibility, to darkness, to bisexuality, to the wilderness, and to an eclipse of sun or moon" (Turner, 95). "Rites of passage" or "transition" are marked by three phases: separation, margin (or limen signifying "threshold" in Latin) and aggregation (Turner, 94). These three stages are noticed in the Narasimha myth: inversion of the world (separation), life in inversion (marginal or liminal/transitional), and return to dharma (aggregation).

An important context in which one encounters Narasimha in the religious life of Andhra Pradesh is the main entrance of the house. It is also common that the main entrance is adorned with yantras or mudras symbolically representing the divine, and Narasimha seals are also commonly utilized for this purpose, since liminal beings such as bhüta, preta, and piśācas (ghosts, ghouls, and spirits) are said to be controlled by Narasimha.

Similarly, disease represents an inverted and transitional phase in one's life. In an extension of the concept of transition, disease signifies the dark phase of inversion and transition (Vemsani 2012:27-29). Hence, as the master of transitions, Narasimha is also associated with disease riddance. Vows (diksha) of penance are undertaken as devotional offerings to Narasimha for curing disease. Although religious vows are commonly referred to as vrats, vows undertaken with regard to Narasimha and Ayyapa by male devotees are commonly referred to as diksha, thereby noted as Narasimha dìksha and Ayyappa diksha respectively. These vows are normally undertaken for the duration of forty days in which devotees undertake the vow of initiation (diksha) with food, sleep, and behavioral restrictions. At the end of the forty days another ritual, dìksha viramana (giving up initiation), marks the end of the liminal state of the vow. The Narasimha temple in Yadagirigutta of Telangana state is especially popular for disease-curing properties, and the God Narasimha of Yadagirigutta acquired the popular sobriquet, the Ārogya Narasimha (Narasimha of Health) among the devotees. 
Recitation of the Narasimha mantra is considered to cure disease (Vemsani, 2016: 153154). Recitation of the Narasimha mantra, undertaking Narasimha diksha, and religious penance, as well as the theater festival of Varahuru come together in the life of Narayana Tirtha (Vemsani, 2016:157), who wrote and composed one of the most popular dance-drama performances known as Krishnalilatarangini (Nagarajan 1988) after he was cured of stomach pain as he performed the Narasimhadiksha. Narayana Tirtha started the Bhägavatamela tradition of Varahuru and, who is also known for creating the Andhranatyam style of dancedrama in Addanki region of Andhra Pradesh. Liminal stages or liminal beings are connected to Narasimha in the mythology; similarly, ritual and devotional traditions also represent this aspect of Narasimha. Devotional and performance traditions represent the reversals, transitions and transformations also represented in the theology of Narasimha.

Theater is associated with various aspects of religious ritual across the world. The theater festivals in eastern India as well as on the Island of Bali are understood to contain magical elements that are representative of containment and controlling of the demonic forces (Emigh, 1981: 21-39). Elsewhere in the neighborhood of India, East Asian ritual opera is well-known for having numerous operatic rituals commonly performed at funerals as well as several other ritual plays commonly staged to ward off ghosts (Johnson, 1989: 1-46). Almost all the theater festivals of India held in the temples are frequently lumped together under a single category of religious performance. However, the theater festivals conducted in connection with Narasimha are categorically different, and the meaning is only subtle in the representation of transitions and transformations ${ }^{18}$.

Numerous performance and ritual traditions are associated with Narasimha in India $^{19}$. The Bhāgavatamela (theater festival in South India) begins on the Narasimhajayanti ${ }^{20}$ with ritual worship offered to Narasimha. Ritual Narasimha masks are used as part of some temple festivals, while in others dance-drama performances are held involving the subject of Narasimha followed by other subjects over a period of three to fifteen days. These ritual masks are then stored away in the temple and never taken out or leave the compound of the temple. The masks are never taken out or exhibited outside of the context of Narasimhajayanti festival, since the masks are considered auspicious representations of the divine. It is remarkable that the Metropolitan Museum of Art, New York, has acquired a collection of masks used in theater festivals during Narasimhajayanti to organize an exhibit, since private collectors and museums in India find it difficult to acquire such masks (Guy, 2015). This again is in line with the conviction of the transitional nature of the Narasimha avatāra and Prahlāda legend. Hence, the divine appearance is celebrated in the form of the masks only on that day that is considered the day of the divine appearance of Narasimha (Narasimhajayanti), and they are not shown outside the ritual context at any other time. The masks are considered as the true representation of Narasimha, and it is believed that Narasimha's presence is felt in the masks during the performance following the ritual worship offered to Narasimha. Hence, the masks of Narasimha and are considered to curtail evil in the context of the theater. Hence it is not merely a theater show but a transformative and 
transitive ritual. The actor donning the mask of Narasimha is said to be temporarily functioning under the possession of Narasimha to end evil in order to bring about positive energy.

Extensive dance dramas are staged during the Bhāgavatamela festival, usually beginning with the performance of the play Bhakta Prahläda on the first day. Three popular theater and dance traditions of South India, Kuchipūdi, Āndhranātyam and Yakshagāna, are usually utilized in the performances held during the Narasimha Jayanti festival in Andhra Pradesh, Karnataka and Tamil Nadu. During the Bhāgavatamela performances, which may traditionally last for three to fifteen days (although currently they may only last between one to three days), numerous subjects are performed that center on devotion, in addition to the play Bhakta Prahlāda.

Three aspects of ritual and religious practice associated with Narasimha reveal the relevant notions of liminality, transition and transformation noted in the classical mythology of Narasimha. The association of Narasimha with liminality/transitions leading the liminal being successfully to a good life is at the center of the popular rituals and religious practices associated with Narasimha. Narasimhayantra and mantra on doors, Narasimha diksha to cure disease and fulfil other fearful states of mind and body, as well as the theater festival of Narasimhajayanti considered to represent symbolic presence of the deity indicate the strong connection of Narasimha with liminality and transitions. These are the central themes consistently noted in the myths of Narasimha as well as religious practices associated with Narasimha.

\section{Conclusion}

My examination of Narasimha myths in this paper revealed that the incarnation of Narasimha embraces the features associated with demons such as a lion face and the sanguinary nature, although these qualities are helpful to overthrow evil rather than to represent evil. Hence, the God Narasimha embraces transitions and liminality, finally leading to transformation. These concepts are then associated with God and evil in popular practice such as theater and religious festivals (Narasimhajayanti). Evil in the Narasimha myth is represented by reversals due to an inverted world order as a result of excessive desire, anger, and greed of the demon Hiranyakaśipu, while God represents transition, a temporary state of disorder, and final transformation. In its conception as well as utility the incarnation of Narasimha indicates an emphasis on transformational and transitional qualities. Narasimha represents divinity in multiple and complex ways: Narasimha is equally representative of Vishnu as his incarnation (avatāra) as well as vyūha Samkarshana, in his cosmic role. The representation of Narasimha as avatāra and vyūha simultaneously represents involvement of Narasimha within creation as avatāra and as vyūha beyond creation. The role of Narasimha in identifying himself with reversals while transforming the world order (dharma) back to harmony forms the background of the theater festival celebrated in connection with Narasimha on Narasimhajayanti. The make-shift arrangements of the theater shows symbolically represent the temporary transformations and divine representations of Narasimha. Ritual practices associated with folk festivals and theater festivals further emphasize the transitional nature of Narasimha. Theater festivals especially begin with the worship of 
Narasimha, which represents the presence of Narasimha through the transformation experienced by the actors who play the character of Narasimha in the theater shows during the festival. This paper analyzed the multi-faceted nature of the Narasimha myth to understand the cosmological design of dharmakarma as it is related to the balance between good and evil in the three worlds (trilokkas), and in addition this paper also analyzed how these qualities of the divine are symbolically represented in popular practice and ritual.

\section{Acknowledgements:}

This paper is a revised version of my presentation titled, "Narsimha, No Boundaries: Evil and Good in Myth and Practice," at the Annual Meeting of the American Academy of Religion 2015 in Atlanta

\section{Notes}

${ }^{1}$ According to Hinduism, there are four yugas (Krita, Treta, Dvāpara, and Kali) in each Kalpa. The ratio between good and evil changes across the four yugas. Evil is not present in Kritayuga, while evil prevails about a quarter over good in Tretayuga, evil prevails half over good in Dvāparayuga, and evil prevails three-quarters over good in Kali yuga. See Balslev.

${ }^{2}$ Telangana is a new state created in 2014 with ten districts separated from erstwhile Andhra Pradesh state, with which it shares numerous cultural traditions including the regional myths (Narasimhapuranamu), rituals and festivals of Narasimha (see Narasimhacarya 1989a; 1989b). Hence, even though Telangana is not a coastal state, it is home to one of the largest and most popular traditions of Narasimha. In fact, Narasimha was declared the state deity of Telangana in 2014 by the state's first Chief Minister K. Chandrashekhara Rao. Western states of India such as Maharashtra and Karnataka also preserve unique Narasimha traditions as part of the panel: God and Evil in Hindu and Christian Theology, Myth, and Practice of the Society of Hindu-Christian Studies. I thank Dr. Lance Nelson, University of San Diego, for inviting me to join the panel and motivating me to present my research on Narasimha. My greatest thanks are to our editor of the Journal of Hindu-Christian Studies, Dr. Bradley Malkovsky, University of Notre Dame, to whom I am greatly indebted for his advice and support on earlier versions of this paper. I would also like to thank my friend, R.L. Mohl, Interpretive Specialist, Hopewell Mound Historic Museum and Site, Hopewell, OH, for his animated discussion and keen reading of earlier versions of this paper. I would also like to thank the two anonymous reviewers of my paper for their valuable comments.

(see, Sontheimer, 2004), although it is not as widely practiced as in the states on the east coast of India.

${ }^{3}$ The lion motif is only partially noticed in Buddhist and Jain stories. Some Hindu myths of Siva and Śakti also incorporate the lion motif in representing minor aspects, although a fully formed deity of lion form is lacking, which is characteristic of Narasimha. I discuss the relationship of such minor Śaiva and Śākta representations in relation to Narasimha in my paper, "God Narasimha as End of Time (Kālānta): Śaiva and Śākta Correlation of an Avatāra of Vishnu" currently under review with the Journal of Royal Asiatic Society.

${ }^{4}$ The wife of Narasimha is sometimes referred to as Simhavalli, although usually she is referred to as Laxmi or as Chenchulaxmi, her human incarnation. Although scholars postulated that the lion motif may have been associated with tribal religion, it appears to have been misinformed analysis for lack of any substantial evidence supporting an independent lion God or Goddess other than that of Narasimha and his 
derivative forms. Early evidence of Narasimha avatāra can be traced back to at least 300 B.C.E. (Bhita Caturvyūha). Two reasons can be provided here on why Narasimha's appearance from mountain Goddesses might not be a feasible theory. First, the lion-faced Goddesses are derived from Narasimha, according to the purānas. In fact, the reasons for the association of Narasimha and Goddesses is the other way round than previously postulated. See Eschmann. Lion-faced Goddesses are said to have been created by Narasimha (Kürmapurāna 179.36; Mastyapurāna CLXXIX 40-90.) Hence, the Mātrikas or a transitional (temporary) representation of leonine Goddesses worshipped by the tribals can be understood to have been derived from Narasimha and are as such worshipped as forms of Narasimha. Besides, the association of lions with caves is ubiquitous in India, which is also reflected in the classical texts and story literature such as the Pancatantra and Brihatkatha dated as early the Mahābhārata (300 B.C.E-300 C.E.). Second, the association of Narasimha with giri (mountains) or the location of his temples in caves might just represent the leonine nature of the deity Narasimha rather than his origin from an unnamed mountain Goddess noted as 'girija' (born of mountain), in the analysis of Eschmann. Eschmann considered the female 'leonine' deity (Goddesses) worshipped by tribals of Orissa to have been the source for the Narasimha (Jagannatha temple, Puri) in his 'girija'- mountain born aspect. The placement of Narasimha within Vishnu/Krishna temples is not unique to the Jagannatha temple, and Narasimha is commonly noticed in most of the Vaishnava temples across the eastern coastal states of Orissa, Andhra Pradesh and Tamilnadu. See Vemsani, 2016.

There are two issues with considering Narasimha to be of tribal origin here. First, the classical texts only support the view of Narasimha giving rise to other lion forms associating him with other Mātrikas, but no story is ever recounted, even in folk contexts, of the Goddesses giving rise to male lion forms similar to Narasimha or of any other God. See Coburn, 1996.
Secondly, that Narasimha's origin is noted to have been from emptiness within a pillar in classical as well as folk narratives, Narasimha is never depicted as arising out of a cave or hill (girija-born of hill). Therefore, folk festivals or folk representations of lion face or cat face Goddesses only indicates local popular practice with regards to Narasimha worship as a representation of his relationship with Mātrikas, but it does not indicate any established notions of the Goddesses serving as surrogates for the origin of Narasimha.

${ }^{5}$ Hinduism depicts the lion in numerous other aspects of divinity. The lion motif appears commonly in connection with Durga Simhavāhini, as a vāhana (mode of transport). However, the incorporation of lion is not as extensive in the above examples as in the case of Narasimha. Complete appearance of the divine in the form of lion is characteristic of only God Narasimha.

${ }^{6}$ According to Hinduism, there are four yugas (Krita, Treta, Dvāpara, and Kali) in each Kalpa. The ratio between good and evil changes across the four yugas. Evil is not present in Krita yuga, while evil prevails about a quarter over good in Tretayuga, evil prevails half over good in Dvāparayuga, and evil prevails three-quarters over good in Kali yuga. See Balslev.

${ }^{7}$ For more details on karma and its application to life and Hindu theology see, Chapple, 1986.

${ }^{8}$ Life of individuals on the Earth in this world and its connection to the other worlds led McKim Marriot to apply the term, dividuals, to represent fluid identities of individuals in Hinduism, sometimes spanning across world and multiple lives. See Marriott, 1976; 1989. For a general understanding of dharma and its role in the order of the worlds see Holdrege, 2004.

9 Hiranyakaśipu acquires notoriety in connection with child abuse and especially for punishing his own children. He is connected to Kamsa in his mistreatment of children. In another cycle of stories connected with Krishna and Balarāma, Hiranyakaśipu curses his children, who are collectively known as Shadgarbhas, to remain as fetuses, confining them to a life of perpetual 
imprisonment in what is termed womb-water-house (jalagarbhagrihe). The Shadgarbhas were born to Devaki later and were killed by Kamsa. See, Suneson, 1983.

${ }^{10}$ The length of Hiranyakaśipu's penance ranges between 1100-1150 years, and while some versions of the story do not mention the length of time; some versions mention as long as 100,000 years for the duration of his penance. It can be understood from the descriptions of the texts that Hiranyakaśipu lived during the last part of Kritayuga (1,728,000 years), which might have been the last 28000 years of the Kritayuga (Mastya purāna 161.2; Harivamsa 226.2 \& 41; Brahma purāna 213.44). Hence, a major part of his life should have been spent performing his penances. See Zimmer.

${ }^{11}$ Anger and desire are also noted as the foremost sins of all, since they lead to numerous vyassanas (vices) that result in negative karma. Manudharmasāstra lists 10 vyasanas caused by desire (vii.47) and eight vyasanas from anger (vii.48). Arthasāstra (VIII.3) lists four vyasanas arising from desire and three from Anger. A second list in Manudharmasāstra (vii.51 - vii.52) coincides with this Arthasāstra list of vices and sins. However, it can be noted that there is agreement between the law texts (Arthasāstra and Manudharmasāstra) as well as the Bhagavadgita, all of which rate desire, anger, and greed as the foremost sins.

${ }^{12}$ Words have several meanings. Lion when used in different contexts may indicate different meanings. Indian religions such as Hinduism, Jainism and Buddhism preserve numerous references to the use of lion motif in symbolic contexts, indicating strength in connection with divinity, leaders and rulers. It is in symbolic contexts that the lion motif appears in Goddess' myths etc., in Hinduism. Narasimha myth and sculptures of Narasimha are datable to as early as 300 B.C.E., thus making Narasimha one of the oldest representations of God as lion. Incidentally, symbolic use of the lion concept is also noticed in Christian antiquity. In Augustine's De Doctrina Christiana (De Doctrina Christiana. PL 34, 3.25.6) the lion motif is used in a similar view demonstrating transitions and identities in the physical world. It states, "The variation takes two forms. In this way one thing signifies another thing and, moreover, another. This is done either in such a way that the second thing signified is different from or contrary to the first...This is the situation where the lion is used to signify Christ when it says 'the lion of Judah has prevailed,' but also signifies the devil when it is written: 'your adversary, the devil, goeth as a roaring lion seeking whom he may devour.'

${ }^{13}$ Rāhu and his mother Simhika (sister of Hiranyakaśipu) are described as possessing lion-face, while her children are commonly referred to as Simhikeyas (Brahmāndapurāna II.6.20; Vāyupurāna. 68.19-20). Simhika is the daughter of Kasyapa and Diti and sister of Hiranyāksha and Hiranyakaśipu (Brahmāndapurāna II.5.12-13; Vāyupurāṇa 67.60). It may be possible that Vishnu might have acquired the qualities associated with the family of Hiranyakaśipu, through his lion-face, since lion-face is explicitly identified with the sister of Hiranyakaśipu.

${ }^{14}$ Therefore, it seems fitting that Narasimha generally appears as the middle avatāra in the normative avatāra lists, symbolic of the transitions the Narasimha incarnations represents. In the standardized list of dasāvatāras Narasimha appears as the fourth, while in the long list of twenty-two avatāras as noted in the Bhāgavatapurāna (2.7.14) Narasimha is listed as the twelfth avatāra, and in the most extensive lists which include forty avatāras Narasimha appears as the twentieth avatāra, thus Narasimha is always placed in the middle of the list of incarnations representing the transitional nature of the divinity represented by Narasimha.

${ }^{15}$ For lack of space and also relevance, I am able to include limited information on vyūha and Vaikuntha forms of Vishnu here in the paper. See Srinivasan, 1979.

${ }^{16}$ For further information on avatāra and vyūha correlation of Narasimha please see my paper, "Narasimha form of Vishnu: Avatāra and Vyūha Correlation in Myth and Practice," currently under review with Journal of South Asian Religious History. 
17 Regional purānas (Sthala purānas) present Narasimha as continuing to roam of the forests of Andhra Pradesh past the death of Hiranyakasipu even though the classical texts do not include such information. See Narasimhacarya, 1989; Narasimhapuranamu, 1968.

18 There are numerous varieties of theater festivals associated with a number of Hindu deities in India. Theater festivals associated with Rāma, staged during the nine days Rāmanavami (Rāmlila); theater festivals associated with Krishna (Krishnalila) celebrated at different times and places; and the theater festivals associated with the Goddess Durga, celebrated during the nine days of Devinavaratris are all theologically different in nature and performance and belong to different genres of performative presentation. Performances associated with Siva, such as Jakkulu, Oggu katha etc., belong to yet another performative genre of oral narrative. Lion dance, mask dances performed during the Devinavaratris differ from Bhāgavatamela and other theater festivals associated with Narasimha.

${ }^{19}$ I discuss ritual and devotional traditions associated with Narasimha in Vemsani 2016.

${ }^{20}$ Narasimhajayanti is celebrated on Vaiśākha Śkla Caturdaśi according to Hindu calendar, which normally occurs in the summer month of May. It is considered the day on which Narasimha appeared on Earth in that form.

\section{Bibliography:}

Agnipurāna. Dutt, Manmathanath. Ed. 1967. Varanasi: Chowkamba Sanskrit Series.

Agrawala, R.C. 1976. "Baladeva and Lion-crowned Plough," Journal of Oriental Institute, Baroda, Vol. XVII: 281-283.

Bhāgavatapurāna . Tagare, Vasdeo Ganesh-1976-78. New Delhi: Motilal Banarsidass.

Balslev, Anindita Niyogi. 1983. A Study of Time in Indian Philosophy. Wiesbaden: Otto Harrsowitz. dx.doi.org/2027/mdp.3901501 1914259

Biardeau, Madeline. 1976. IV. Études de Mythologie Hindoue (IV) [II. Bhakti et avatàra]. Bulletin de
l'Ecole française d'Extrême-Orient, 63(1): 111-263. http://dx.doi.org/ 10.3406/befeo.1976.3888

Brahmāndapurāna . Sastry, J.L. 1973. Ed. New Delhi: Motilal Banarsidass.

Brahmāpurāna . Ed, trans. Schreiner, Peter, Renate Sohnen. 1987. Wiesbaden: Otto Harrassowitz

Chapple, Christopher. Karma and Creativity. Albany: SUNY, 1986.

Coburn, Thomas. 1996. "Devi, The Great Goddess" in John S. Hawley (ed.) Devi Goddesses of India. Berkley: University of California Press. pp. 31-49.

Creel, Austin B. 1986. "Contemporary Philosophical Treatments of Karma and Rebirth," Karma and Rebirth: Post Classical Developments. Ed. Ronald W, Neufeldt. Albany: SUNY, 1-15.

Eliade, Mircea. 1959. Cosmos and History: The Myth of the Eternal Return. New York: Harper \& Row.

Emigh, John. 1984. Dealing with the demonic: strategies for containment in Hindu iconography and performance. Asian Theatre Journal, 1(1), pp. 21-39. http://dx.doi.org/ $10.2307 / 1124364$

Eschmann, Annacharlotte, 1978. "The Vaishnava Typology of Hinduization and the Origin of Jagannatha." Eschmann, Annacharlotte, Hermann Kulke, Gayacharan Tripathi. The Cult of Jagannatha. New Delhi: Manohar: 97-114.

Gail, Adalbert. 1983. "On the Symbolism of Three and Four Faced Visnu images: A Reconsideration of Evidence." Artibus Asiae. Vol. 44. 297-307. http://dx.doi.org/10.2307/ 3249614

Grünendahl, Reinhold and Schreiner, Peter. 1997. Nārāyanìya-Studien (Vol. 6). Otto Harrassowitz Verlag. http://dx.doi.org/ 2027/mdp.39015041760029

Gupta, M. Shakti. 1974. Vishnu and his incarnations. Bombay: Somaiya Publications. http://dx.doi.org/2027/uc1.b3935997

Guy, John S. 2015. Roaming the Land: Narasimha's Journey from Mythic Hero to Bhakti Worship: The Lion Avatar in South Indian Temple Drama. http://www.metmuseum.org/press/exhibitions /2015/encountering-vishnu. Metropolitan Museum of Art: New York. 
Harivamśapurāna of Punnāta Jinasena. Edited with Hindi translation. Pannalal Jain. Kashi: Jñapapîţa Mūrtidevī Granthamāla, 27. Bharatiya Jnanapitha Publications, 1962.

Hacker, Paul, 1959. "Zur Entwicklung der avatāra Lehre," Kleine Schriften. Wiesbaden: Franzsteiner Verlag GMBH. 404-483.

Holdrege, A. Barbara. 2004. "Dharma." In Susheel Mittal. Ed. The Hindu World. Routledge: London. pp. 213-248.

Johnson, David. 1989. "Actions Speak Louder Than Words." In D. Johnson, Ed. Ritual Opera Operatic Ritual. Berkely: University of California. pp. 1-46. Kloetzli, Randy and Alf Hiltebeitel 2004. "Kāla," in Susheel Mittal. Ed. The Hindu World. Routledge: London. pp. 553-586.

Kūrmapurāṇa. Ed. Trans. Anand Swarup Gupta. 1972. Varanasi: Kashiraj Trust.

Marriott, McKim. 1976. "Hindu Transactions: Diversity without Dualism." In Bruce Kapferer. Ed. Transaction and Meansing: Direction in the Anthropology of Exchange and Symbolic Behavior. Philadelphia: Institute for Humane Issues. pp. 109-42.

1989. "Constructing an Indian Ethnosociology." Contributions to Indian Sociology 23 (1):1-39. http://dx.doi.org/10.1177/0069966 89023001003

Mastyapurāna . Chandra, Vasu Srisa. 1974. Sacred Books of the Hindus 17.2. New York: AMS Press.

Meister, Micheal W. 1996. "Man and Man-lion: The Philadelphia Narasimha." Artibus Asiae 56 (3-4): 291-301. http://dx.doi.org/10.2307 /3250120

Nagarajan. B. 1988. Srikrishnaleela Tarangini. Madras: Mudgala Trust.

Narasimhacharya, M. 1989a. History of the Cult of Narasimha in Andhra Pradesh. Hyderabad: Sri Malola Grantha Mala, Ahobalamath. http://dx.doi.org/2027/mdp.39015021591097 . 1989b. History of the Cult of Narasimha in Telangana. Hyderabad: M. Radha and Sons. http://dx.doi.org/2027/mdp.39015021591097
Narasimhapurānamu (Telugu) of Erra Pragada. Veluri, Sivaramasastry. 1968. Ed. Madras: Vavilla Ramaswamy Sastrulu \& sons.

Otto, Schrader. 1942. "Narasimha." Vishwabharati Quarterly. Vol. I. Pt. II.:17.

Padmapurāna. Mora, Mansukharaya. Gurumandal Series no 18. Calcutta: Gurumandal, 1957.

Pal, Pratapaditya. 1973-74. "A Brahmanical Triad from Kashmir and Some Related Icons." Archives of Asian Art Vol. 27: 33-46.

Rosen, Steven (Satyaraja Dasa). 2001. "Neither Here Nor There: Exploring the Borders with Narasimha." Back to Godhead. May/June Issue. pp. 24-27.

Śivapurāna, Ed. J.L. Shastri. 1969. Ancient Indian Tradition and Mythology. Vol. 1-4. Delhi: Motilal Banarsidas.

Skanda purānas Vol. 1-4. Bakker, Hans. Ed. 1998-2006. Groningen: E. Forsten.

Smith, Brian. 1994. Classifying the Universe: The Ancient Indian Varna System and the Origins of Caste. New York: Oxford University Press.

Soifer, Deborah. 1991. The Myths of Narasimha and Vamana. Albany: State University of New York Press.

Sontheimer, Gunther G. 1989. Pastoral Deities in Western India. New York: Oxford. . 2004. "Folk Deities in the Vijayanagara Empire: Narasimha, Mallanna/Mailar." Eds. Heidun Bruckner, Anne Feldhaus, and Aditya Malik. Essays on Religion, Literature and Law. New Delhi: Manohar. 147-72.

Śrīnarasiṃhapurānam. Jena, S. ed., 1987. New Delhi: Nag Publishers.

Srinivasan, Doris. 1979. "Early Vaishnava Imagery: Caturvyūha and Variant forms." Archives of Asian Art Vol. XXXII: 39-55.

Suneson, Carl. 1993. "The Shadgarbha tradition in the Harivamsa, the purānas and the Krishnacaritranātaka of Ranajit Malla," Proceedings of the VIII World Sanskrit Conference, Wiener Zeitschrift Kunde Süd (und Ost) Asiens 36. Supplement Band: 197-211. 
Mahābhārata Critical Edition. Vol I, II 1927. Ed. Suktankar, V.S.. Bhandarkar Oriental Research Institute: Poona.

Tripathi, G.C. 1987. "The Ritual of Daily Puja in the Jagannatha Temple of Puri: An Analytical Approach." Journal of the Asiatic Society. Vol. XXIX No. 2: 83-93.

Tull, Herman, W. 1989. The Vedic Origins of Karma: Cosmos as Man in Ancient Indian Myth and Ritual. Albany: SUNY: Albany.

Turner, Victor. 1995. The Ritual Process: Structure and Anti-structure. Transaction. Ithaca, NY: Cornell Paperbacks, Cornell University Press.

Gennep, Arnold Van. 2011 (original print 1909). The rites of passage. Chicago: University of Chicago Press.

Vayupurāna. Tagare, Ganesh Vasdeo. Ed. 1987-88. Delhi: Motilal Banarsidass.

Vemsani, Lavanya. 2006. Hindu and Jain Mythology of Balarāma. New York: Edwin Mellen.
2009. "Narasimha, the Supreme Deity of Andhra Pradesh: Tradition and Continuity in Hinduism-An Examination of the Temple Myths, Folk Tales, and Popular Culture," Journal of Contemporary Religion 24.1: 35-52. http://dx.doi.org/10.1080/13537900802630489

2012. "Worms and the Corporal Body in India," Parasites, Worms, and the Human Body in Religion and Culture. Ed. Gardenour, B., and Misha Tadd. New York: Peter Lang, 17-41. http://dx.doi.org/10.3726/978-1-4539-0263-9 . 2016. "Narasimha Mantra as a Connection between Classical, Regional, Devotional, Artistic and Ritualistic Traditions: Tradition and Practice in Andhra Pradesh," Journal of Vaishnava Studies 21.2:147-161

Visnudharmottarapurāna. Grünendahl, Reinhold. 1983-89. Wiesbaden: Otto Harrassowitz.

Zimmer, Heinrich, R. 1942. "The Hindu View of World History According to the purānas." Review of Religion 6.3: 249-269. 